\title{
Multiple metasomatism of the lithospheric mantle beneath the northeastern North China Craton
}

\author{
LA ZHANG, YONGSHENG LIU, LINA WANG, \\ CHENGYUAN WANG AND GANGLAN ZHANG
}

China University of Geosciences (Wuhan)

Presenting Author: lazhangg@163.com

Mantle xenoliths carried by the Cenozoic basalts in Huinan are composed of harzburgite, dunite, lherzolite, wehrlite, and pyroxenite. These rocks provide an opportunity to trace the composition and evolution of the lithospheric mantle beneath the northeastern North China Craton (NCC). Major and trace element analyses reveal that the primary compositions of these xenoliths are widely modified by partial melting and multistage metasomatism. Three types of metasomatic agents are identified based on the geochemical features of clinopyroxene. The high ${ }^{87} \mathrm{Sr} /{ }^{86} \mathrm{Sr} \quad(>0.7065)$, high $\mathrm{Ti} / \mathrm{Eu}$ but low $\mathrm{Ca} / \mathrm{Al}$ ratios of clinopyroxene core in one refractory harzburgite indicate an early metasomatic event caused by subducted Paleo-Asian Oceanic slab-derived high- ${ }^{87} \mathrm{Sr} /{ }^{86} \mathrm{Sr}$ silicate melts. The variation trend of clinopyroxenes in harzburgite, dunite, and wehrlite xenoliths in the plot of $\mathrm{Ti} / \mathrm{Eu}-(\mathrm{La} / \mathrm{Yb})_{\mathrm{N}}$ indicate the overprinting of subsequent carbonatite metasomatism. The low ${ }^{87} \mathrm{Sr} /{ }^{86} \mathrm{Sr}$ ratio $(<0.7035)$ of carbonatite melts suggest an origin of the asthenosphere mantle. In addition, ${ }^{87} \mathrm{Sr} /{ }^{86} \mathrm{Sr}$ ratios of clinopyroxenes in some pyroxenite and dunite xenoliths increase with increasing $\mathrm{U} / \mathrm{Zr}$ and $\mathrm{Ti} / \mathrm{Eu}$ ratios, while in some harzburgites, they decrease with increasing $\mathrm{U} / \mathrm{Zr}$ and $\mathrm{Ti} / \mathrm{Eu}$ ratios. These features together suggest a later metasomatic event caused by fluid-bearing silicate melts with moderately high ${ }^{87} \mathrm{Sr} /{ }^{86} \mathrm{Sr}$ ratio $(\sim 0.7048)$, which were suggested to be related to the subduction of the Paleo-Pacific Oceanic slab. Considering the multistage mantle metasomatism widely recorded in the NCC, we speculate that the early mantle metasomatism could have played an important role in the thinning of the NCC. 